Georgia has brokered peace deals, helped to see off despots such as Panama's Manuel Noriega and still found time to spend one week each year building houses for the needy.

But Carter's most lasting accomplishment is likely to be disease eradication. Last year, just 22 people in 4 countries in sub-Saharan Africa had Guinea-worm disease, compared with the 3.5 million who suffered the parasitic infection in one year in the mid-1980s, when the non-profit Carter Center in Atlanta, Georgia, began to lead a global campaign to wipe out the disease.

The former president spoke last week at a meeting to drum up support for Guinea-worm-eradication efforts, barely showing his 91 years or his fight with cancer (he revealed last year that he has metastatic melanoma). He has said that he wants the last Guinea worm to leave the world before he does, and he may also live long enough to see the back of another global menace: the three-decade effort to eradicate polio is nearing completion. The virus is now present in only Afghanistan and Pakistan, which together recorded an all-time low of 73 cases last year.

Neither disease will go without a final struggle. Violence and political instability threaten both efforts, and a Guinea-worm epidemic in dogs in Chad demonstrates the unpredictability of disease eradication. But both campaigns have come too far and cost too much to be left incomplete, and world leaders should provide the resources needed to finish the jobs.

What next? Carter is among those who would like to see other diseases exterminated. His centre launched the International Task Force for Disease Eradication, which has drawn up a list of candidates, including measles, mumps and lymphatic filariasis (a parasitic infection also known as elephantiasis). "We're ready and eager to go on several diseases," Carter said. He even needled the World Health Organization for its sluggishness in adopting Guinea-worm eradication as an official goal, and its reluctance to target other diseases for eradication.

Carter might be right on Guinea worm, but given the tools available to twenty-first-century science and medicine, is an all-out assault to eradicate disease still the best way to go?

Putting the fight against a pathogen on a pedestal can warp efforts to tackle other diseases and develop health systems. Amid regular

door-to-door campaigns to deliver oral polio vaccines, northern Nigeria had (and still has) low rates of routine childhood vaccination for diseases such as measles and diphtheria. (Officials have argued that future eradication campaigns could do more to improve health systems, for instance by starting eradication efforts in a particular country only once routine immunization coverage reaches a certain threshold.)

The Guinea-worm and polio campaigns have been decidedly oldschool in approach. The main tool against polio has been a decades-old

"Eradication success spares countries from the economic burdens of a disease."

report cases to health authorities.
Future eradication campaigns have obvious appeal. Although they are costly, success spares countries from the economic burdens of a disease. Guinea-worm efforts have also helped to provide clean drinking water to millions of people in some of the world's poorest and most remote areas. And eradication is an appealing target that can court donors who might not otherwise support public health.

Future eradication campaigns (and other public-health efforts) should find inspiration in the fact that Guinea-worm eradication has been focused on behavioural change, but they are likely to have other approaches to choose from. One of the most promising is gene-drive technology, which allows a gene that is harmful to a pathogen or vector to rapidly spread through a sexually reproducing population.

Last year, two teams developed experimental gene drives that made mosquito populations infertile or resistant to malaria. It will be years before the technology is ready for field trials. But it is one reason that people are beginning to talk seriously again about malaria eradication, after failed efforts in the 1950s and 1960s.

Gene drives could also be applied to other vector-borne infections, including tick-borne infections such as the bacteria that cause Lyme disease. President Carter's hit list may yet grow longer.

\section{Outside the bubble}

\section{Governments must stop proposing solutions and invest in large-scale removal of carbon dioxide.}

$\mathrm{E}$ very generation throws a different hero up the pop charts, sang musician Paul Simon. And every political cycle, it seems, promotes its own signature solution to the problem of how to curb and prevent climate change. This year's answer is bioenergy with carbon capture and storage - a plan on a colossal scale to grow grass and trees on an area half the size of the United States, harvest and ship this biomass to power stations, burn it and then trap the carbon dioxide from the exhaust gases. The greenhouse gas would then be piped underground and stored indefinitely. The scheme's acronym - BECCS - barely does its complexity justice.

Perhaps this is the first you have heard of BECCS. That wouldn't be a surprise. It is something of an overnight sensation - the boy band launched to number one on the back of a reality television show, rather than the grizzled rockers who earned their fame after years of concerts attended by three people and a dog. Yet at the Paris climate talks late last year, which were widely acclaimed as a triumph, the BECCS scheme was quietly installed as the world's Plan A.

That's because it comes with a very catchy tune that politicians can't get out of their heads. BECCS solves the problem of future carbon emissions and cleans up the past. The plants suck $\mathrm{CO}_{2}$ from the atmosphere, which ends up safely underground. We get the benefit of burning them to generate electricity, the world gets to keep its power infrastructure, and the atmosphere experiences what BECCS enthusiasts call negative emissions. Rather brilliantly, the more energy the scheme produces, the more the planet edges away from dangerous levels of global warming.

What's not to like? Well, in a World View article published after the Paris talks, climate scientist Kevin Anderson compared BECCS to a fairy godmother, conjured up to wish away reality in a puff of optimism (see Nature 528, 437; 2015). And in a Comment piece on page 153, environmental scientist Phil Williamson takes a hard look at some of the questions that BECCS seems to pose, and finds few answers.

How would we preserve forests and grasslands, faced with such a demand for energy crops? How much carbon would be released during the agricultural stage? How much water will we need, and where will we get it? How much will it cost to build the network of compressors, pipes, pumps and tanks that will be needed to liquefy and transport the separated $\mathrm{CO}_{2}$ ? Can it even be separated at a sensible cost?

Recent years have seen a series of solutions to global warming thrown up the political agenda. From biofuels and carbon offsets to ocean fertilization and conventional carbon capture, each has had its moment in the sun, only to be replaced by something younger with a new sound.

BECCS may yet prove to have staying power. But to avoid another one-hit climate wonder, governments must spend the money to do
SNATURE.COM To comment online, click on Editorials at: go.nature.com/xhunqv the groundwork - as Williamson says - and Politics is the art of the possible. But serious action on climate change must be based on the science of the probable. to answer those questions and plenty more. 